\title{
Synthesis and Atiplatelet of 2-(ethyl amino acid esters), Amino pyridyl 1,3- oxzine
}

\author{
M.S Al-Ajely \\ Chemistry Dept. College of Education, \\ Mosul University,Mosul-Iraq
}

\section{Abstract}

2-(N-glycyl ,Alanyl, leucinyl , isoleacinyl , methionyl, phenyl alanyl, vilinyl methyl ester) , 2-Amino and 4- Amino pyrideyl -1,3- Benzoxazine -4- one were synthesized from the reaction of the corresponding amino acids ester, Amino pyridines with methyl cyano salicylate using improved method. The resulted benzoxazine derivative were tested for their Antiplatelet inhibitory activity, their IR, NMR $\left({ }^{1} \mathrm{H},{ }^{13} \mathrm{C}\right)$ were also studied and checked by elemental analysis.

Keywords: Antiplatelet,1,3 oxazine, amino acid esters inhibitory activity

\section{Council for Innovative Research}

Peer Review Research Publishing System

Journal: Journal of Advances in Chemistry

Vol 2, No. 2

editor@cirworld.com

www.cirworld.com, member.cirworld.com 


\section{Introduction}

Some researchers prepared amino oxazine compounds from the reaction of malonyl chloride and alkyl cyanamide1 .some amino acid ester derivatives of 1,3-benzoxazine were prepared from the reaction of 7-chloro -2-alkyl thio-1,3-pyrano oxazine-4-one with the corresponding amino acid esters2. Some 1,3-pyrano oxazine compounds were prepared and showed antimicrobial activities against broad spectrum of bacteria and fungi3,4. 7-chloro-2-methyl thio -2-ethyl carbazate of 1,3- pyrano oxazine was found to have anti tumor activities according to joint research with ( $\mathrm{NCl}$ ) 5 . Several types of 7and2-disubstituted amino acid esters and peptide derivatives of 1,3-pyrano oxazine were found to have antibacterial activities6,7. 2-Morpholino substituted benzoxazine compounds were prepared from the reaction of substituted Salicylic acid, triphenyl phosphine dibromide and lead thiocyanate with morpholine. This morphoino 1,3- benzoxazine product gave significant antiplatelate activity8. Accordingly this finding which may help prevent blood clots in heart attack patient received national recognition especially in Australia, So research in medicinal chemistry hoped to improve drugs that thin the blood for heart attack, strokes and angina (chest pain ) sufferers. The above investigation gave early biological results and encourages us to develop new drugs that may overcome of the side effects associated with existing drugs and that is the main of our investigation in preparing new derivatives of 1,3- benzoxazines.

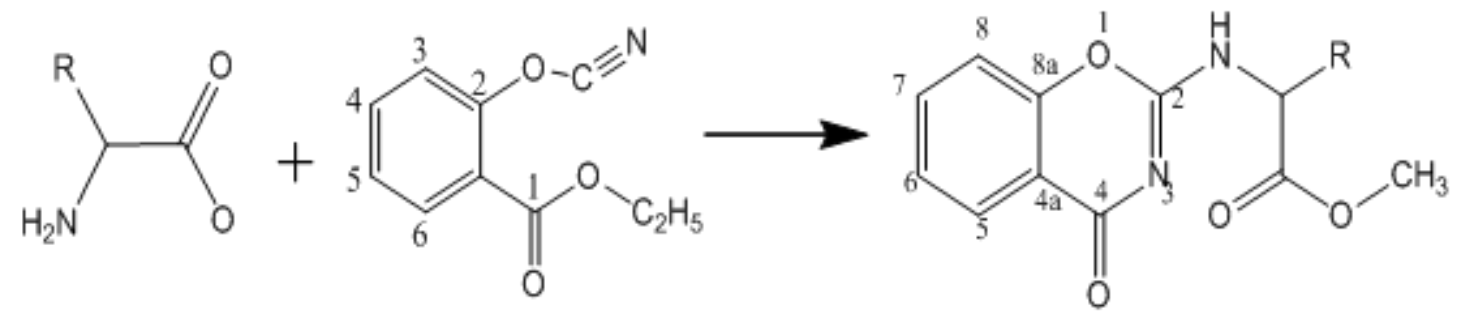

$\mathrm{R}_{1}=\mathrm{H}$

$2=-\mathrm{CH}_{3}$

$3=-\mathrm{CH}_{3} \mathrm{CH}_{2} \mathrm{CHCH}_{3}$

$4=-\mathrm{CH}_{2} \mathrm{CH}(\mathrm{CH} 3)_{2}$

$5=-\mathrm{CH}_{2} \mathrm{CH}_{2} \mathrm{SCH}_{3}$

$6=-\mathrm{CH}_{2} \mathrm{Ph}$

$7=-\mathrm{CHRNH}=-\mathrm{N}$

$8=-\mathrm{CH}\left(\mathrm{CH}_{3}\right)_{2}$

$9=$<smiles>CNc1cccnc1</smiles> 
$10=$
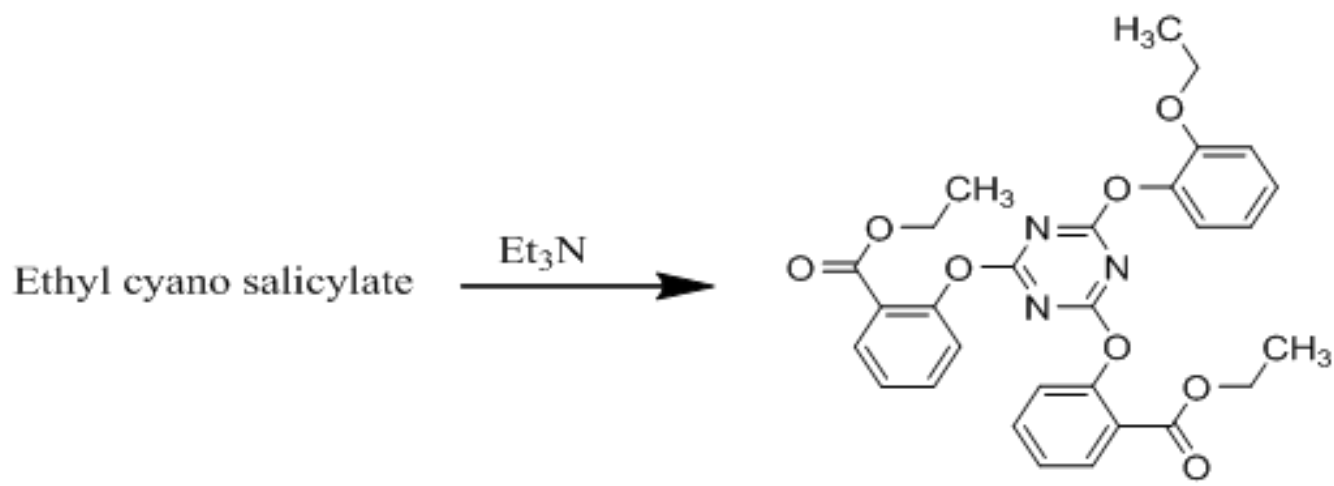

(Trimer product)

(Scheme 1)

\section{Experimental}

All melting points were measured using stuart scientific(smp3) melting point apparatus and are uncorrected.

IR spectra were measured using Perkin Elmer FTIR instrument, 1H,13C NMIR spectra were performed using Bruker Ac $200 \mathrm{MHz}$ spectrometer at 200 and $50 \mathrm{MHz}$ respectively, All 1Hand13C NMR spectral result are recorded as chemical shifts $(\delta)$ and in the case of $\mathrm{CDCl} 3$ are relative to internal TMS while chemical shifts recorded in DMSO-d6 are relative to the solvent peak of 2.5 and $39.4 \mathrm{ppm}$ respectively. Elemental analysis were measured in chemical and micro analytical services Pty. Ltd. (Belmont) victoria, Australia

\section{Amino acid methyl ester Hydrochloride salts \\ General procedure}

Following the procedure of pirkle etal9 .The amino acid $(11.0 \mathrm{mmol})$ was combined with anhydrous methanol $(500 \mathrm{ml})$ in $100 \mathrm{ml}$ round bottomed flask equipped with stirring bar. The mixture was cooled to $00 \mathrm{C}$ in an ice/water bath for $30 \mathrm{~min}$ thionyl chloride(1.1equivalent) was then added dropwise with vigorous stirring. The flask was sealed with a latex balon and stirring contained for $24 \mathrm{~h}$, The resulting clear solution was concentrated in vacuo to a volume of approximately $10 \mathrm{ml}$. On cooling in ice, the methyl ester hydrochloride precipated as a white solid which was collected, washed with ether then recrystallised from approperate solvent. The purified products were characterised by melting point, $1 \mathrm{H}, 13 \mathrm{CNMR}$.

\section{Amino acid methyl ester}

\section{General procedure10}

The amino acid ester hydrochloride salt $(10 \mathrm{mmol})$ was combined with (chloroform $910 \mathrm{ml})$ in $50 \mathrm{ml}$ round bottom flask .To the stirred solution was added dropwise a solution of triethyiamine (1.0equivalent) in chloroform (10ml), the mixture then stirred for $4 \mathrm{~h}$ ar room temperature. The mixture was heated at $700 \mathrm{c}$ for $1 \mathrm{~h}$ then cooled to room temperature and concentrated in vacuo to a white solid .the solid was diluted with ether, filtered and washed with a further $10 \mathrm{ml}$ of ether. Concentration of the ether, filtered and washed with a further $10 \mathrm{ml}$ of ether. Concentration of the ether filtrate in vacuum gave the amino acid ester free amine.

\section{Synthesis of O-cyno salicylate ethl ester}

Following the same published procedure 11 of the reaction between cynogen bromide and ethyl salicylate, the distillation of the final solution was carried out under reduced pressure. The first fraction which distilled at 64 oC and a pressure of 3.5×10-2 was mainly of un reacted ethyl salicylate. 
The second fraction which distilled at $64 \mathrm{oC}$ and a pressure of $3.5 \times 10-2$ was found as a mixture of the un reacted salicylate and some of dimethyl cyanate. The third fraction distilled at $78 \mathrm{oC}$ and a pressure of $3.6 \times 10-2$ was found as pure cyanosalicylate.

\section{Synthesis of 2-(N-amino acid methyl ester)1-.3-Benzoxazine-4-ones General procedure12}

The amino acid ester $(0.01 \mathrm{~mol})$ was combined with dry acetonitrile $(20 \mathrm{ml})$ in $50 \mathrm{ml}$ round bottom flask equipped with dropping funnel and calcium chloride tube. The flask was surrounded with an ice cooled water maintained at $0 \circ \mathrm{C}$, while the cynosalicylate $(0.01)$ was dissolved in $20 \mathrm{ml}$ of dry acetonitrile in separating funnel. Addition of the cynosalicylate solution to the stirred amino acid ester was completed within one hour .fter the complete addition of the cynosalicylate ,the reaction mixture was stirred for further $3 \mathrm{hs}$ maintaining the temperature all the time at $0 \mathrm{oC}$.The reaction mixture was left to stand on deep freezing for $12 \mathrm{~h}$.the precipitated solid was washed with ether and recrystallised three times from petroleum ether (60-80oC) then from toluene.

\section{2-(N-glycylmethylester)-1,3- Benzoxazine-4-one(compound1)}

White crystalline solid,(70\%yield) m.p.192-194oC; 1HNMR (CDCl3) $\delta 10.59(\mathrm{~s} 1 \mathrm{H} \mathrm{NH}), 8.11,8.07(\mathrm{~d} 1 \mathrm{H}), 7.60(\mathrm{t} 1$ $\mathrm{H}), 7.3(\mathrm{t} 1 \mathrm{H}), 7.16(\mathrm{~d} 1 \mathrm{H})$ for aromatic protons, 6.29(s1 $\mathrm{H} \mathrm{NH}), 4.35(\mathrm{~d} 3 \mathrm{H} \mathrm{OCH} 3)$ 3.80(d2HCH2)2 forms compound;13CNMR(CDCl3)ठ 168.34.4,166.23, 168.34.4,166.23,155.34,153.89, 155.34, 153.4, 155.34, 153.89, 136.08, 134.31, 132.27, 127.74, 126.28.84, 53.71,49.56; IR(KBr) 3473.30 (NH), 1748(CO ester) 36,1697.51 (CO of Oxazine ring ), $1573(\mathrm{C}=\mathrm{N})$; Anal. Calcd. For C H N, C;56.41, H; 4.30,N; 11.96 Found C;56.50, H;4.41, N; 12.03.

\section{2-(N-Alanylmethylester)-1,3- Benzoxazine-4-one(compound2)}

White solid compound (59\% yield),m.p.159-161oC;1H (CDCL3200MHz): $\delta 8.1(\mathrm{~d} 2 \mathrm{H}), 7.6(\mathrm{t} 1 \mathrm{H}), 7.3(\mathrm{t} 1 \mathrm{H}), 7.2(\mathrm{~d} 1 \mathrm{H})$ aromatic protons,6.3(dNH),4.9 $(\mathrm{m} \mathrm{1H})$ asymmetric proton),3.8(s3H), 1.6(d3H); 13C(CDCl3 200MHz) $\delta 173.34$, 167.52.89, 134.56,128.100, 126.33,126.28, 177.82, 115.87, 53.17for $\mathrm{CH}, 50.21$ for OCH3 ; IR(KBr) $3240(\mathrm{NH})$, 1752.09(CO ester), 1680.23(CO Oxazine ring), 1560(C=N).

\section{2-(N-Isoleucinyl methyl ester)-1,3-Benzoxazine-4- one(compound3)}

White crystalline solid(60\%yield),m.p.127-128 oC ; $1 \mathrm{H}(\mathrm{CDCll3} 200 \mathrm{MHZ}) \quad \delta 8.03(\mathrm{~d} \mathrm{I} \mathrm{H}), 7.58(\mathrm{tlH}), 7.30(\mathrm{t} 1 \mathrm{H}), 7.16(\mathrm{~d}$ I $\mathrm{H})$ Aromatic protons, $6.42(\mathrm{dNH}), 3.82(\mathrm{~s} 3 \mathrm{H}), 1.49(\mathrm{~m} 2 \mathrm{H}), 1.30(\mathrm{~m} \mathrm{I} \mathrm{H}$ asymmetric proton), $0.98(\mathrm{~m} 2 \times 3 \mathrm{H}) ; 13 \mathrm{C}(\mathrm{CDCl} 3200 \mathrm{MHz})$ $172.73,167.45,158.62, \quad 154.01,134.63,128.08,125.89,117.82,115.85,58.85,52.90,38.06,25.52,15.77,12.08$; $\operatorname{IR}(\mathrm{KBr}) 3235.86 \quad(\mathrm{NH}), \quad 1751.17(\mathrm{CO}$ ester),1677.26(CO Oxazine ),1603.35(C=N);Anal.Cal. for CHN,C;62.0 6,H;5.14,N;10.21 Found,C;62.16,H;6.31,N;9.70 .

\section{2-(N-Leucinyl methyl ester)-1,3-Benzoxazine-4-one(compound 4)}

White crystalline solid (54\%yield) m.p.124-125 oC;1H (CDCl3200MHz) 88.07 , (d I H), 7.75(t I H), 7.29(t $1 \mathrm{H}), 7.29(\mathrm{t} 1$ $\mathrm{H}), 6.25$ (d I H)Aromatic protons ,6.23(dNH),4.95(m asymmetric proton), 3.80(sOCH3), $1.79(\mathrm{~m} 2 \times 3 \mathrm{H}) ; 13 \mathrm{C}(\mathrm{CD} \mathrm{Cl} 3200 \mathrm{MHz})$ $174.09,167.47,158.52,154.06,134.60,128.10,126.48,125.87,117.84,11604,115.83$; IR(KBr) $3240.49(\mathrm{NH}), 1751.67(\mathrm{CO}$ ester), $1618.66(\mathrm{C}=\mathrm{N})$.

\section{2-(N-Methionyl methylester)-1,3-Benzoxazine-4-one(compound 5)}

The product was solid compound 40\%yield,m.p.130-131 oC;1H (CDCl3200M H11.4(dNH),8.1(t | H),7.6(t I H),7.3(d | $\mathrm{H})$ Aromatic protons,6.2(sNH), 5.0 ( $\mathrm{mCH}$ asymmetric proton), $3.8(\mathrm{~s} 3 \mathrm{H}$ of $\mathrm{OCH} 3,2.6(\mathrm{q} 2 \mathrm{H}$ of $\mathrm{CH} 2 \mathrm{~S}), 2.38(\mathrm{~m} 2 \mathrm{H}$ of $\mathrm{CH} 2 \mathrm{C})$, $2.2(\mathrm{~s} 3 \mathrm{H}$ of $\mathrm{CH} 3 \mathrm{~S}), \quad 13 \mathrm{C}(\mathrm{CDCL} 3200 \mathrm{MHz}) ; 171.40,167.47,162.74,161.41,155.10,150.93,137.05$, $134.29,132.22,128.27,126.86,126.11,125.89,124.24,124.20,117.74,61.68(\mathrm{OCH} 3)$ one signal, 54.84, 53.32 at 32.07 (SCH3), 30.15I IR $(\mathrm{KBr}) 3240.76(\mathrm{NH}), 1753.04(\mathrm{CO}), 1618.6(\mathrm{C}=\mathrm{N})$, The open compound gave about 35\%yield with m.p.128-160 oC and 1HNMR spectrum showed signals at $4.3(\mathrm{q} 2 \mathrm{H})$ and triplet at 1.3ppm,together with the rest protons of the compound.13CNMR spectrum confirms the open structure through the signal at $15.89,14.63$ related to the $\mathrm{CH} 3$ of $\mathrm{OCH} 2 \mathrm{CH} 3$.

\section{2-(N-phenylalanyl methyl ester)1,3 benzoxazine-4-one (compound 6)}

White crystalline solid (65\% yield),m.p.125-125 oC; $1 \mathrm{H}(\mathrm{CDCl} 3200 \mathrm{MHz}) \quad 8.1(\mathrm{q} 2 \times 1 \mathrm{H}), \quad 7.6(\mathrm{~m} 2 \times 1 \mathrm{H}), \quad 7.3(\mathrm{~m} 2 \times 11 \mathrm{H})$, $7.1(\mathrm{q} 2 \times 1 \mathrm{H})$ Aromatic protons, $6.1(\mathrm{qNH}), 5.2(\mathrm{~m} 1 \mathrm{H}$ asymmetric proton),3.8(d3H of OCH3),3.33(dofd2H with asymmetric CH) $13 \mathrm{C} ; \mathrm{CDCl} 3200 \mathrm{MHz}) 171.5,167.1,157.5,153.7,135.3,134.312$ 9.4,128.8, 127.8,127.7, 127.4,125.7, 117.5,115.6, $54.8,52.8,37.5$

This compound showed two forms which when heated to $60 \mathrm{oC}$ showed the following resonating signals:171.81, 167.0,158.06, 154.44,135.96, 134.50, 1229.39, 129.22, 128.44, 127.83, 126.14, 118.37, 115.97, 55.62, 52.98,38.35; $\mathrm{IR}(\mathrm{KBr}) 3379.38(\mathrm{NH}), 1774.57$ (CO ester)1605.18 ( $\mathrm{C}=\mathrm{N})$, Anl.Calc CHN, C;66.66, H;4.96,N; 8.64, Found, $\mathrm{C} ; 66.72, \mathrm{H} 5.09, \mathrm{~N} ; 8.53$

2-(N-Valinyl methyl ester)-1,3-Benzoxazine-4-one (compound 7) 
Sold compound (63\%yield),m.p.159-161 oC;1H (CDCl3)200MHz) $88.0(\mathrm{~m} 1 \quad \mathrm{H}), 7.7(\mathrm{~m} 1 \mathrm{H}), 7.4(\mathrm{~m} 1 \mathrm{H}), 7.0(\mathrm{~m} 1 \mathrm{H})$ Aromatic protons showed two forms, 3.9 $(\mathrm{m} 1 \mathrm{Hof} \mathrm{CH}), 3.8(\mathrm{~d} 2 \times 3 \mathrm{HofOCH} 3), 2.2(\mathrm{~m} 1 \mathrm{H}), 1.4(\mathrm{~m}(1 \mathrm{H}), 1.0(\mathrm{~m} 2 \times 3 \mathrm{H})$ of $\mathrm{CH}$. This compound showed simplified spectrum when heated to $403 \mathrm{~K}$ temperature which is fastening the eneamine-amine exchange.

\section{The trimer (the cyanate trimeritization)}

\section{1-The ethyl cyano salicylate}

1HNMRspectrum gave the following signals:

$10.89(\mathrm{sOH}), 8.05(\mathrm{~d} 1 \mathrm{H}), 7.64,6.5(\mathrm{~m} 2 \mathrm{H}), 7.39(\mathrm{t} 1 \mathrm{H}), 4.43(\mathrm{q} 2 \mathrm{H}), 1.44(\mathrm{t} 3 \mathrm{H})$ which in consistent with sigma Aldrich 13CNMR;163.66for estercarbonyl,15 1.82for carbon 2,134.67C6, 133.17forC4, 127.47forC5 ,121.16 forC1,117.14 forC3,108.86for $=\mathrm{N}, 62.34,14.53$ for $\mathrm{CH} 2, \mathrm{CH}$, respectivelylR (neet) showed strong absorption peak at 22.94 related to $\mathrm{C}=\mathrm{N}$ triple bond.

\section{2-The trimer}

This compound was prepared from the reaction of $(1 \mathrm{~g}$. ) of ethyl cyanosalicylate with one drop of triethylamine at room temperature, the solid was recrystallized from petroleum ether(60-80 oC),95\%yield, mp.97-99oC(published:97-98oC

1HNMR $(\mathrm{CDCl} 3) \quad 8.1(\mathrm{~m} 1 \mathrm{H}), 7.8(\mathrm{~m} 1 \mathrm{H}), 7.5(\mathrm{~m} 1 \mathrm{H}), 7.4(\mathrm{~m} 1 \mathrm{H})$ aromatic protons showed more than one form,4,3(m2H),1.2(3s for three types ofCH3 protons; 13CNMR(CDCl3200MHz) 167.91, 164.39, 160.65, 154.37, 150.78, 135.6, 134.84, 134.16, 132.85, 128.49, 127.57, 127.18, 126.57, 123.81,123.71,123.22,117.02 which showed more than one type of aromatic carbons indicating the non planarity of these aromatic rings, $61.78,14.46$ for $-\mathrm{OCH} 2, \mathrm{CH} 3$ respectively; $\mathrm{IR}(\mathrm{KBr})$ showed $1724.0 \mathrm{~cm}-1$ forester, $1613 \mathrm{~cm}-1$ forC $=\mathrm{N}$.

\section{2-(N-Prolinyl methyl ester)-1,3- Benzoxazine-4-one(compound8)}

Solid white crystalline compound(62\% yield), mp.132-133 oC.

1HNMR; $\delta$ 8.15(q2types ofH),7.36 $(\mathrm{m} 1 \mathrm{H}), 7.28(\mathrm{~m} 1 \mathrm{H}), 7.16(\mathrm{~m} 1 \mathrm{H}), 4.85,4.41 \quad$ (twotypes of $\mathrm{CH}), 4.72(\mathrm{~m}$ part of the praline ring nearst to $\mathrm{N}$ atom(ene-amine interchange) $4.66(\mathrm{~d} 2 \times 3 \mathrm{H}), 2.10$ ( $\mathrm{m}$ proline rotons).

13CNMR(CDCI3)172.15,171.91,167.13,166.89

(different types of C=O) (C2,C8a),134 .21, 134.129 C5 (two types), 127.93, 127.88 C7 ( two types), 125.87,125.77 C6 (two types), 117.84.117.65 C4a (two types), 115.85, 115.63C8 (two types), 60.08, 59.45-OCH3 (two types,53.05, 52.78 for praline carbons next to nitrogen,48.63,46.98for praline ring carbons,30.97,30.0 for other praline ring carbons,23.99,23.55 two types of the rest praline carbons.

Heating the compound to 60 oC the NMR showed the following resonating signals ;172.05,154.30,134.0,128.20,118.35,115.75 as sigle signals together with the following aliphatic carbons60.01,59.91(two signals for $-\mathrm{OCH} 3,52.68,48.35,47.4$ (brod signal),30.30(broad signal), 23.92 which means thatsome carbons becomes single signal due to collecience temperature while the broad signals were near to collecience.

The IR spectrumshowed the following absorption signals; $1748.42 \mathrm{Cm}-1$ for the este rmoiety, $1672 \mathrm{Cm}-1$ for $\mathrm{C}=\mathrm{N}$ of oxazine ring,Anal.Calc forCHN,C;61.31,H;5.14,N;10.21,Found,C;61.28,H;5.21.N;10.27

\section{2-(N-3-Amino pyridyl)1,3-Benzoxazine-4-one (compound9)}

Bronish yellow powder(70\% yield), mp.203-204 ${ }^{\circ} \mathrm{C}$.

${ }^{1} \mathrm{HNMR}\left(\mathrm{DMSOd}_{6} 200 \mathrm{MHz}\right) 10.96$ (broad NH),8.75(d ortho toNH),8.66(d para to $\left.\mathrm{NH}\right), 7.8(\mathrm{~d}$ orthotoNH),7.9(d meta to $\mathrm{NH}$ of the praline ring), $7.81(\mathrm{~d} 1 \mathrm{H}), 7.74(\mathrm{~m} 1 \mathrm{H}), 7.4(\mathrm{~m} 1 \mathrm{H}), 6.97(\mathrm{~d} 1 \mathrm{H})$ Aromatic protons.

${ }^{13} \mathrm{CNMR}\left(\mathrm{DMSOd}_{6}\right) ; \mathrm{C} 4 \mathrm{C}=\mathrm{O}$ at167.34,160.36,159.57 for non protonated carbons,153.51for C8a,C2, 144.90 for C10.,142.54 forC14,134.0 forC7,128.18 for C5, 126.21 forC13,124.81 forC6,122.62 forC12,119.47 for C4a,115.23 for C8.

IR $(\mathrm{KBr}) \mathrm{cm}^{-1} 3413.70 \mathrm{NH}, 1689.30,1624.06,1609.12,1557.82$ for $\mathrm{C}=\mathrm{N}, \mathrm{C}=\mathrm{C}$ Aromatic respectively.

\section{Preparation of Compound 10}

This compound gave the lowest yield $(10 \%)$ due to the resonance withdrawal effect of the amino pyridine ring. The compound showed high mp.,above $300{ }^{\circ} \mathrm{C}$ and was insoluble in any common solvent except hot DMF and was recrystallized from acetic acid.The ${ }^{1} \mathrm{HNMRspectrum}\left(\mathrm{DMSOd}_{6}\right)$ Heated to4 20K) showed the followingresonating signals $\delta, 8.79$ (broad ),8.50,8.45 as broad signals,6.93(broad for NH). Anal.calc. for CHN, C; 65.27.H; 3.79.N; 17.56, Found, $\mathrm{C} ; 53.87, \mathrm{H} ; 4.71 . \mathrm{N} ; 28.33$, The calculated value did not fit with oxazine structure,So we suggest that the compound is pyridylcarboimide and not an oxazine type.

${ }^{1} \mathrm{HNMR}$ of compound10 gave the fowling resonating signals $\delta 8.3(\mathrm{~d}), 6.6(\mathrm{~d}), 4.2$ for $\mathrm{NH}$ while ${ }^{13} \mathrm{CNMRDMSO}$ heatedto470K)gave the following signals170.88,149.41,14.04, 145.24, 137.45,134.03, 114.21, 113.82

The IR (KBr) gave the following absorption $\mathrm{Cm}^{-1}$; $3436.32 \mathrm{NH}, 1650.62,1601,1507.98$ for $\mathrm{C}=\mathrm{N}, \mathrm{C}=\mathrm{C}$ of pyridine ring. 


\section{Antiplatelet measurments8}

Venous blood was collected from drug free volunteers into trisodium citrate $22.0 \mathrm{~g} / \mathrm{l}$.Ethics approval was obtained from LaTrobe university Human ethics commitittee(HRECNumber06-16). The whole blood was centerfuged at 130gfor15minat roomtemperature to obtain platelet rich plasma(PRP). Theremining blood was centerfuged for $10 \mathrm{~min}$ at $820 \mathrm{~g}$ inorder to obtain platelet poor plasma(PPP).Platelet aggregation was determinedby the opticamethod in two-channel platelet aggreometer (Chrono-Log).Assy were carried outat $37{ }^{\circ} \mathrm{C}$ andhad atotal volume of $500 \mathrm{ml}$. after addition of the test compound and agonist.Stirring rate was $1000 \mathrm{rpm}$ with the PRP and test compound being pre-incubated for 2 min before the addition of the appropriate agonist. The agonists used ADP (final concetration $10 \mathrm{mM}$ ) and collagen (final concentration $4 \mathrm{mg} / \mathrm{ml}$.).

Test compounds were dissolved in ethanol or DMSO depending on solubility and added in $3 \mathrm{ml}$ volumes for ethanol and 2 $\mathrm{ml}$.volume for DMSO. The samples dissolved in DMSO were added in 2 ml.volumes to ensure that the final concentration of DMSO was kept below $0.5(\mathrm{v} / \mathrm{v})$ which made certain that the DMSO would not influence platelet aggregation. Aggregation was recorded after the addition of the agonist and results were compared to platelet aggregation in the presence of an equivalent amount of test vehicle(Ethanol orDMSO). The concentration of compound at which the aggregation was inhibited by $50 \%$ (ICO) was determined as the average of multiple determination(Three or more) where platelet aggregation was reduced by $50 \%$.

\section{Results and discussion}

All compounds except compound (7) gave a traces amount of an open chain compound through their NMR of the crude products which shows the resonating signals of the ethoxy group protons at $\delta 1.3-1.4 \mathrm{ppm}$ as triplet and quartet at $4.34 \mathrm{ppm}$. This open compound of each was not cyclized even in refluxing of the crude product for $4 \mathrm{~h}$. which means that the following structure prevent the cyclization.

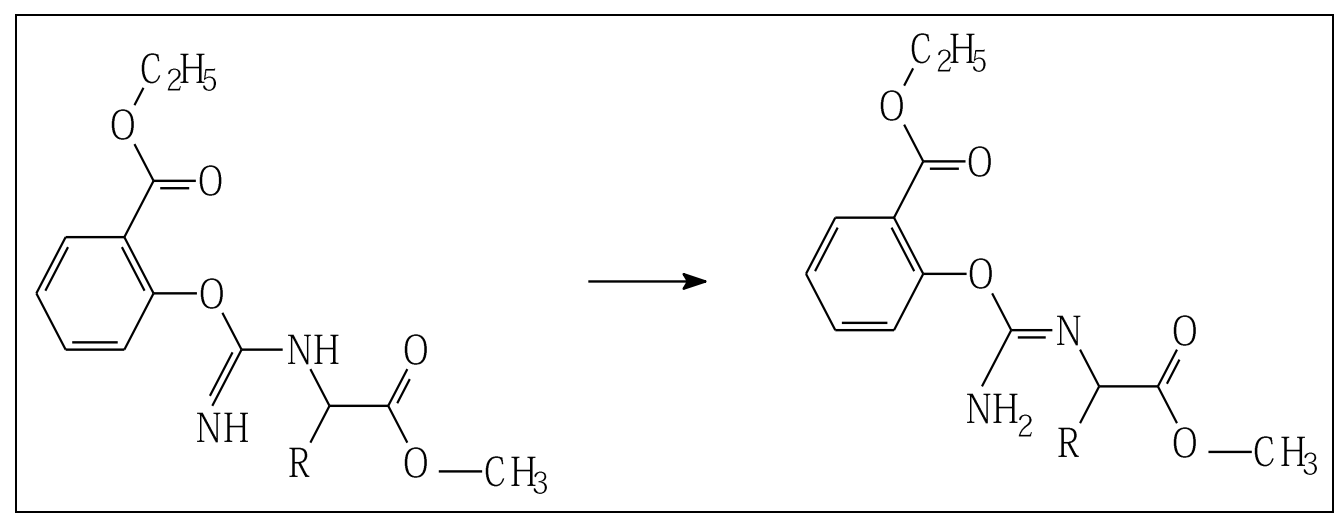

The lone pair of electrons resonate to a form which cause the $\mathrm{NH}$ proton faraway from the carbonyl group to be cyclised. These traces of open compounds were comes off during recrystallization. While in methionine products it was about $50 \%$ of the crude product which could be easily identified.

This finding was supported by other researchers worked on similar compounds ${ }^{12}$.It was also found that chirality and anisochronacy in(magnetic non equivalence) as a result of chirality some of the amino acid moiety showed magnetically not equivalent protons and ${ }^{13} \mathrm{C}$ chemical shift for chemically equivalent groups ${ }^{14}$

The ${ }^{1} \mathrm{H}$ NMR and ${ }^{13} \mathrm{C}$ showed double signals due the imine structures , The following structure shows the following two forms:<smiles>[R]C(N=c1[nH]c(=O)c2ccccc2o1)C(=O)OC</smiles>

It is worth noting here that our general procedure for the preparation of the oxazine compounds was the improved one while the indicated procedure before improvement ${ }^{3}$ gave $16 \%$ yield for the morpholino oxazine while using this improved method morpholino oxzine yield becomes $90 \%$ yield. This improvement will encourage researchers and the industry to use this method in synthesizing these important compounds . 
Some selected samples of the oxazine amino acid esters were tested for their antiplatelet effect and were fount to have poor action but 3-amino pyridyl compound(9) gave significant effect among the tested compounds.

The trimer preparation method is also novel one because it was previously prepared by refluxing ethyl salicylate with cynuric chloride in $73 \%$ yield ${ }^{13}$ while in our method no need for using cynuric chloride.

\section{Acknowledgment}

The author would like to thanks Endeavour Australian scholarship team for offering the postdoctoral followship and thanks also due to LaTrobe University School of Pharmacy and Applied Science for providing the facilities to do this work.

\section{References}

1. W.Riad, J. Nenninger and J.W. Bats . Chem. Ber, 118,4707 (1985).

2. J.M.A. Al-Rawi and M.S. Al-Ajely, J. of Educ . and Sci , 10 , 39 (1990).

3. M.S. Al-Ajely and K.D. Sulaiman, J. of Educ. And Sci , 7 , 99 (1989).

4. A.H. Al-Mosusawi, J.M.A. Al-Rawi and M.S. Al-Ajely, Arab Gulf J. Sci, Res., 9, 1 (1991).

5. M.S. Al-Ajely and F.T.Al-Abachi, Iraq, patent No.2807 (2000).

6. H.A. Basheer PhD. Thesis, College of Education, Mosul University Mosul-Iraq (2000).

7. M.S.AlOAjely, H.A. Basheer, National J. of Chemistry 28,695 (2007).

8. M. Kaylane. Pritchaid, PhD. Thesis, LaTrobe University Bendigo, Melbourne,Victoria, Australia (2007).

9. W.H Pirkle,.. Pochapskly, T.C. J. Chrometogr , 89, 347 (1989).

10. Ibid, 369,175 (1986).

11. a-Grigat, Ernst, Puetter, Rolf-Farbentabriken Bayer AG, Germany. Chemische Bericht, 97 (11) 3012 (1964). b-Grigat, Ernst, Cologne stammheim and Rolf. Patter vs patent 3,755,402 (1973).

12. Grigat, Est, Patter, Rolfshneided, Ka. Luedemeyer, Karlfried, US patent, 5410922011 (1970)

13. A.W.Van Muijlwijk, A.P.G. Kieboom and H.Van Bekkum, Recueil, Journal of the Royal Netherland Chemical Society , 93,7,204 (1974).

14. D. Jasou . Mc Kerrow, PhD. Thesis, LaTrobe University Bendigo, Melbourne,Victoria, Austrelia (2007). 